\title{
PENAMBAHAN LIMBAH AMPAS TAHU SEBAGAI SUMBER PROTEIN NABATI TERHADAP PERFORMA PERTUMBUHAN IKAN NILA GIFT (Oreochromis niloticus)
}

\section{ADDITION OF TOFU DREGS AS THE SOURCES OF VEGETABLE PROTEIN ON THE GROWTH PERFORMANCE OF TILAPIA (Oreochromis niloticus)}

\author{
Sufal Diansyah ${ }^{1}$, Farah Diana ${ }^{1}$, Agus Suwandi ${ }^{2}$ \\ ${ }^{1}$ Program Studi Akuakultur, Fakultas Perikanan dan Ilmu Kelautan, Universitas Teuku Umar, \\ ${ }^{2}$ Mahasiswa Program Studi Perikanan, Fakultas Perikanan dan Ilmu Kelautan,Universitas Teuku Umar, \\ Jalan Kampus Alue Peunyareng, Meureubo, Meulaboh, Aceh Barat, Aceh 23615 \\ *Korespondensi : sufaldiansyah@utu.ac.id
}

\begin{abstract}
ABSTRAK
Ikan nila (Oreochromis niloticus) merupakan salah satu spesies ikan yang banyak dibudidayakan untuk memenuhi kebutuhan protein hewani. Konsumsi ikan nila mengalami peningkatan yang signifikan dari tahun ke tahun. Peningkatan produksi ikan budidaya berdampak pada tingginya kebutuhan pakan. Permasalahan yang sering dihadapi dalam penyediaan pakan buatan ini adalah biaya yang cukup tinggi.Penelitian ini dilaksanakan selama 45 hari pada bulan Januari sampai Februari 2017 di Unit Usaha Rakyat (UPR) Desa Tumpuk Krueng Kecamatan Betong Kabupaten Nagan Raya. Penelitian ini dilakukan dengan metoda eksperimen, menggunakan Rancangan Acak Lengkap (RAL) dengan empat perlakuan dan tiga ulangan. Perlakuan tersebut yaitu penambahan konsentrasi tepung ampas tahu dengan perlakuan P0 : 0\%, P1: 10\%, P2 : 20\%, dan P3 : 30\%. Parameter yang diamati pada penelitian ini adalah tingkat kelangsungan hidup dan laju pertumbuhan pesifik, dan kualitas air.Derajat kelangsungan hidupikannila yang dipelihara dengan perlakuan penambahan ampas tahu dalam pakan yaitu sebesar 100\%. Laju pertumbuhan harian (SGR) ikan nila yang dipelihara dengan perlakuan penambahan ampas tahu dalam pakan P0, P1, P2, P3, berturut-turut sebesar $0,56 \% ; 2,87 \% ; 1,57 \% ; 1,54 \%$. Nilai SGR maksimum terdapat pada perlakuan P1 yaitu $2,87 \%$, sedangkan nilai SGR minimum terdapat pada perlakuan P0 sebesar $0,56 \%$.
\end{abstract}

Kata kunci: Ika nila, pakan, pertumbuhan, protein.

\begin{abstract}
Tilapia (Oreochromis niloticus) is one of the many fish species cultivated to meet the needs of animal protein. Tilapia consumption has increased significantly from year to year. Increasing the production of aquaculture has an impact on the high demand of feed. The problem that is often faced in the provision of artificial feed is a fairly high cost. This research was conducted for 45 days in January to February 2017 at People's Business Unit (UPR) Tumpuk Krueng Village Betong Sub-District, Nagan Raya District. This study was conducted by experimental method, using Completely Randomized Design with four treatments and three replications. The treatment is the addition of the dregs flour concentration with the treatment of P0: $0 \%, \mathrm{P} 1: 10 \%, \mathrm{P} 2: 20 \%$, and P3: $30 \%$. The parameters observed in this study were survival rate and pace of growth rate, and water quality. The degree of survival of tilapia maintained by the addition of tofu dregs in the feed is $100 \%$. The daily growth rate (SGR) of tilapia maintained by the addition of tofu dregs treatment in feed P0, P1, P2, P3, respectively $0,56 \% ; 2.87 \% ; 1.57 \% ; 1.54 \%$. The maximum SGR value is in P1 treatment that is $2,87 \%$, while minimum SGR value is at treatment $\mathrm{P} 0$ equal to $0,56 \%$.
\end{abstract}

Keywords: feed, growth, protein, Tilapia.

\footnotetext{
${ }^{1}$ Fakultas Perikanan dan Ilmu Kelautan, Universitas Teuku Umar

Korespondensi : Jurusan Akuakultur, Fakultas Perikanan dan Ilmu Kelautan, Universitas Teuku Umar, Kampus UTUMeulaboh, Alue Peunyareng 23615, Telp: +62 85288323477, email: sufaldiansyah@utu.ac.id
} 


\section{PENDAHULUAN}

Ikan nila (Oreochromis niloticus) merupakan salah satu spesies ikan yang banyak dibudidayakan untuk memenuhi kebutuhan protein hewani. Konsumsi ikan nila mengalami peningkatan yang signifikan dari tahun ke tahun. Data FAO (2009) melaporkan bahwa produksi ikan nila dunia terus mengalami peningkatan sekitar 769.936 tontahun 2007 menjadi 2,3 juta ton tahun 2008, sedangkan pada tahun 2010 diperkirakan mencapai 2,5 juta ton (FAO, 2010). Peningkatan produksi ikan budidaya berdampak pada tingginya kebutuhan pakan. Permasalahan yang sering dihadapi dalam penyediaan pakan buatan ini adalah biaya yang cukup tinggi. Menurut Rasidi (1998), biaya pakan ini dapat mencapai $60-70 \%$ dari komponen biaya produksi. Salah satu alternatif yang dapat dilakukan untuk menekan biaya produksi tersebut adalah dengan memproduksi pakan buatan sendiri. Pembuatan pakan buatan harus mempertimbangkan jenis bahan baku yang mudah didapat dengan harga yang terjangkau. Salah satu solusinya adalah dengan memanfatkan sumber-sumber bahan baku lokal, termasuk pemanfaatan limbah hasil industri pertanian yang relatif murah.

Tepung ampas tahu merupakan suatu bahan yang berasal dari sisa industri olahan tahu, sisa olahan tahu ini berupa ampas kacang kedelai kasar yang tidak larut dalam proses pembuatan tahu. Ditinjau dari kandungan nutrisi pada ampas tahu nilai kandungan protein yang terkandung tergolong cukup baik yakni berkisar $\pm 21 \%$. Hal ini dapat menjadi nilai lebih dikarenakan sumber protein ampas tahu berasal dari sumber nabati.Protein adalah bagian dari semua sel hidup organisme dan merupakan bagian terbesar tubuh sesudah air. Protein memiliki fungsi penting sebagai bahan dasar pertumbuhan sel-sel tubuh. Protein tersusun atas dua puluh monomer-monomer asam amino yang berbeda. Nilai mutu protein dinilai dari perbandingan asam-asam amino yang terkandung dalam protein tersebut (Winarno 2008).

Pertumbuhan merupakan proses biologis yang kompleks dengan banyak faktor yang mempengaruhinya. Menurut Effendi (2003) pertumbuhan ikan dipengaruhi oleh dua faktor, yaitu internal yang meliputi sifat genetik dan kondisi fisiologis ikan, dan faktor eksternal yang berhubunga dengan pakan dan lingkungan. Faktor eksternal tersebut diantaranya adalah temperatur, cahaya, oksigen, komposisi kimia, hasil buangan metabolit dan ketersediaan pakan.

Mulia (2014) menyatakan salah satu pilihan sumber protein adalah tepung limbah ampas tahu. Ampas tahu merupakan limbah hasil industri tahu yang kandungan gizinya cukup tinggi. Menurut Mursining (2006) kandungan gizi dalam ampas tahu adalah protein $21,23 \%$, lemak $16,22 \%$, karbohidrat $19 \%$, serat kasar 29,59\%, kadar abu 5,45\%, dan air $9,84 \%$. Berdsarkan uraian diatas, maka perlu dilakukan penelitian tentang penambahan ampas tahu dengan persentase yang berbeda terhadap pertumbuhan ikan nila gift. Penelitian ini bertujuan untuk menganalisis pengaruh penambahan tepung ampas tahu dalam pakan buatan terhadap pertumbuhan ikan gift.

\section{METODE PENELITIAN}

\section{Waktu da Tempat}

Penelitian inidilaksanakan pada bulan Juli sampai dengan Agustus 2017 di Unit Usaha Rakyat (UPR) Desa Tumpuk Krueng Kecamatan Beutong Kabupaten Nagan Raya.

\section{Rancangan Percobaan}

Metode penelitian yang dilakukan secara eksperimental dengan menggunakan rancangan acak lengkap (RAL), penelitian ini menggunakan 4 perlakuan dan 3 kali ulangan. Perlakuan yang diberikan adalah penambahan tepung ampas tahu pada pakan buatan selama 1 bulan dengan berbagai dosis.

$\mathrm{P}_{0} \quad$ : Pakan buatan tanpa penambahan tepung ampas tahu

$\mathrm{P}_{1} \quad$ : Pakan ditambah tepung ampas tahu dengan dosis $10 \%$ 
$\mathrm{P}_{2} \quad$ : Pakan ditambah tepung ampas tahu dengan dosis $20 \%$

$\mathrm{P}_{3} \quad$ : Pakan ditambah tepung ampas tahu dengan dosis $30 \%$

\section{Prosedur Penelitian}

\section{Persiapan wadah}

Wadah pemeliharaan yang digunakan adalah jaring tancap berukuran $1 \mathrm{~m} \times \mathrm{m} \times 50$ $\mathrm{cm}$ sebanyak 12 unit dengan kepadatan ikan 10 ekor $/ \mathrm{m}^{2}$ yang berukuran $\pm 5-8 \mathrm{~cm}$ (SNI 7550;2009). Bagian dasar kolam dilakukan pengeringan, hal ini berguna menghindari kontaminasi bakteri pathogen atau mikroba.

\section{Persiapan tepung}

Tepung ampas tahu dibuat dari ampas tahu kasar, ampas tahu kasar yang diambil berasal dari industri pengolahan tahu didaerah Nagan Raya. Pada awal proses pembuatan tepung ampas tahu; pertama, ampas tahu yang didapatkan dalam keadaan basah dilkukan penjemuran dibawah terik matahari/ menggunakan sinar UV sampai berkurang kadar airnya mencapai $10 \%$ didalam ampas dengan rentang waktu mencapai 3-4 hari, setelah itu ampas yang sudah kering dilakukan pembersihan dan seleksi terhadap ampas yang bagus, Selanjutnya dilakukan penggilingan terhadap ampas dengan ukuran yang diinginkan lalu ampas dimasukan kedalam wadah dan disimpan pada suhu kamar.

\section{Persiapan pakan uji}

Pakan yang diberikan kepada ikan uji yaitu pakan buatan yang telah diformulasikan dengan dosis berbeda, pakan uji ini berupa pellet tenggelam. Adapun bahan baku dan komposisinya sebagai berikut.

Tabel 1. Bahan baku yang digunakan

\begin{tabular}{cccccc}
\hline \multirow{2}{*}{ No } & Bahan Baku yang & \multicolumn{4}{c}{ Formulasi (\%) } \\
\cline { 3 - 6 } & Digunakan & $\mathrm{P}_{0}$ & $\mathrm{P}_{1}$ & $\mathrm{P}_{2}$ & $\mathrm{P}_{3}$ \\
\hline 1 & Tepung Ikan & 24,3 & 24,3 & 24,3 & 24,3 \\
2 & Tepung Kedelai & 25,7 & 25,7 & 25,7 & 25,7 \\
3 & Tepung Tapioka & 25,7 & 25,7 & 25,7 & 25,7 \\
4 & Pelengkap & 20 & 20 & 20 & 20 \\
5 & Dedak & 24,3 & - & - & - \\
6 & Tepung Ampas Tahu & - & 10 & 20 & 30 \\
\hline & & \multicolumn{3}{c}{ pagi pukul 08.00 WIB dan sore pukul 17.00}
\end{tabular}

\section{Persiapan benih ikan uji}

Ikan uji yang digunakan adalah ikan nila (Oreochromis niloticus) berasal dari Unit Usaha Rakyat (UPR) Desa Tumpuk Krueng Kecamatan Betong Kabupaten Nagan Raya. Dipilih ikan nila yang sehat sebanyak 120 ekor dengan ukuran 5-8 cm/ekor. Aklimatisasi ikan dilakukan dengan mengadaptasikan kondisi ikan dari tempat asalnya di tempat yang baru, karena semua perubahan lingkungan bisa dianggap sebagai penyebab stres bagi ikan. Aklimatisasi ikan nila yaitu dilakukan pemuasaan selama satu hari setelah ikan diletakan dalam wadah penelitian.

Pemeliharaan Ikan Uji

Pemberian pakan

Pemberian pakan pada ikan uji dilakukan setiap dua kali sehari yaitu pada
WIB.Pakan diberikan secara ad satiation.

\section{Manajemen kualitas air}

Manajemen kualitas air dilakukan untuk mempertahankan nilai mutu ideal kulitas air, dimana pada kegiatan ini yaitu wadah pemeliharaan dibersihkan setiap tiga hari sekali dan dilakukan pengukuran parameter kualitas air setiap harinya.

\section{Parameter Uji}

Parameter yang diamati pada penelitian ini adalah derajat kelangsungan hidup, laju pertumbuhan spesifik, konversi pakan dan kualitas air.

\section{Tingkat kelangsungan hidup (Survival Rate/SR)}

Kelangsungan hidup benih ikan nila diamati dengan cara menghitung jumalah ikan yang hidup pada sampling terakhir. Persantase kelangsungan hidup benih ikan nila setelah 
pemberian tepung ampas tahu diperoleh dengan menggunakan rumus :

$$
\mathrm{SR}=\frac{\mathrm{Nt}}{\mathrm{No}} \times 100 \%
$$

Keterangan:

SR =tingkat kelangsungan hidup

$\mathrm{N}_{\mathrm{t}} \quad=$ ikan hidup padaakhir penelitian

$\mathrm{N}_{\mathrm{o}} \quad=$ =ikan hidup pada awal penelitian

Laju pertumbuhan harian (Spesific Growth Rate/SGR)

Pertumbuhan harian ikan uji dihitung dengan menggunakan rumus berikut :

$S G R=\frac{L n W t-L n W o}{t} \times 100 \ldots($ Gasper, 2008)

Keterangan :

SGR = rata-rata pertumbuhan harian (\%/hari)

$\mathrm{W}_{\mathrm{t}}=$ rata-rata bobot ikan pada akhir penelitian $(\mathrm{g})$

$\mathrm{W}_{\mathrm{o}} \quad=$ rata-rata bobot ikan pada awal penelitian $(\mathrm{g})$

$\mathrm{T}=$ lama penelitian (hari)

\section{Parameter kualitas air}

Parameter yang diukur untuk pengamatan kualitas air adalah suhu dan pH. Pengukuran dilakukan pada awal, tengah dan akhir penelitian.

\section{Analisis Data}

Data hasil pengamatan dihitung untuk mendapatkan parameter biologi yaitu (SR dan SGR). Data hasil perhitungan ditabulasi dan dianalisis menggunakan program Microsoft Excel 2007 dan SPSS 16.0. Data parameter biologi dianalisis dengan analisis ragam (Anova) pada selang kepercayaan 95\%. Analisis ini digunakan untuk menentukan apakah perlakuan berpengaruh nyata terhadap parameter biologi. Apabila berpengaruh nyata dilakukan uji lanjut Duncan pada selang kepercayaan $95 \%$ untuk menentukan perbedaan antar perlakuan. Parameter kualitas air dianalisis secara deskriptif dengan penyajian gambar atau tabel.

\section{HASIL DAN PEMBAHASAN}

Hasil

\section{Derajat kelangsungan hidup}

Derajat kelangsungan hidupikannila yang dipelihara dengan perlakuan penambahan ampas tahu dalam pakan yaitu sebesar

100\%(Gambar1).HasilperhitunganAnovamen unjukanbahwapenambahan sumber protein nabati menggunakan limbah ampas tahu, tidak berpengaruhnyataterhadapkelangsunganhidupi kannila gift (Oreochromis niloticus).

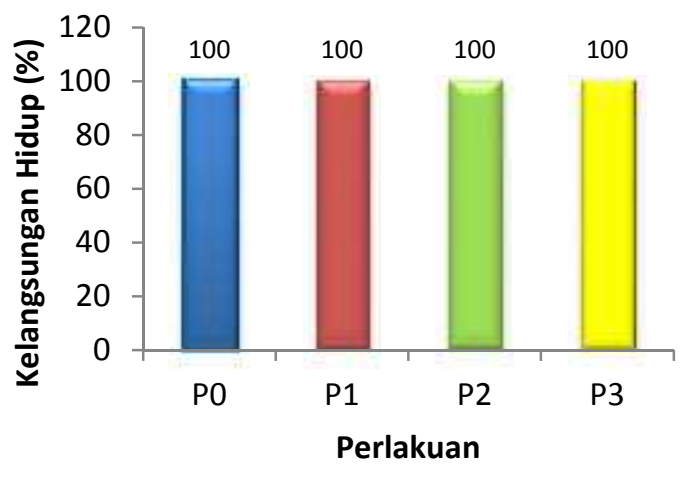

\section{Laju pertumbuhan harian}

Laju pertumbuhan harian (SGR) ikan nila yang dipelihara dengan perlakuan penambahan ampas tahu dalam pakan $\mathrm{P} 0, \mathrm{P} 1$, $\mathrm{P} 2, \mathrm{P} 3$, berturut-turut sebesar $0,56 \% ; 2,87 \%$; 1,57\%; 1,54\% (Gambar 2). Hasil perhitungan Anova menunjukan bahwa penambahan sumber protein nabati menggunakan limbah ampas tahu, berpengaruhnyataterhadaplaju pertumbuhan spesifikikannila gift (Oreochromis niloticus). Nilai SGR maksimum terdapat pada perlakuan P1 yaitu 2,87\%, sedangkan nilai SGR minimum terdapat pada perlakuan P0 sebesar 0,56\%.Berdasarkan hasil uji lanjut Duncan pada selang kepercayaan 95\%, diperoleh hasil berbeda nyata pada setiap perlakuan uji yaitu 0\%, 10\%, $20 \%$ dan 30\%.

\section{Kualitas air}

Adapun parameter kualitas air yang diamati dalam penelitian ini meliputi suhu dan pH. Hasil pengukuran parameter kualitas air selama masa pemeliharaan tersaji pada Tabel 8. 


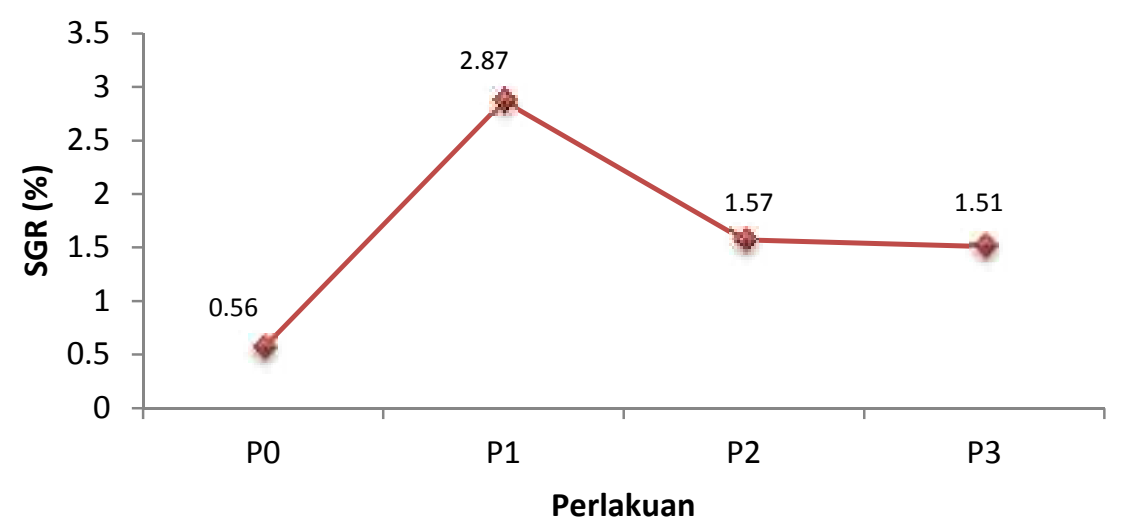

Gambar 2. Laju Pertumbuhan Spesifik Ikan Nila Gift

Tabel 8. Parameter Kualitas Air

\begin{tabular}{|c|c|c|c|c|c|c|c|}
\hline \multirow{2}{*}{\multicolumn{2}{|c|}{ Parameter }} & \multicolumn{4}{|c|}{ Perlakuan } & \multirow{2}{*}{$\begin{array}{l}\text { Nilai } \\
\text { Ideal }\end{array}$} & \multirow{2}{*}{ Referensi } \\
\hline & & $0 \%$ & $10 \%$ & $20 \%$ & $30 \%$ & & \\
\hline \multirow{2}{*}{$\begin{array}{c}\text { Suhu } \\
\left({ }^{\circ} \mathrm{C}\right)\end{array}$} & Awal & 24 & 24 & 24 & 24 & \multirow{2}{*}{$25-32$} & \multirow{2}{*}{ SNI, 2009} \\
\hline & Akhir & 27 & 27 & 27 & 27 & & \\
\hline \multirow{2}{*}{$\mathrm{pH}$} & Awal & 6,9 & 6,9 & 6,9 & 6,9 & & \multirow{2}{*}{ SNI, 2009} \\
\hline & Akhir & 7,3 & 7,3 & 7,3 & 7,3 & $6,5-8,5$ & \\
\hline
\end{tabular}

Parameter kualitas air memegang peranan penting dalam proses pertumbuhan dan kelangsungan hidup ikan nila (Oreochromis niloticus). Hasil pengamatan terhadap kedua parameter kualitas air menunjukkan suhu air selama pemeliharaan berkisar $24-27^{\circ} \mathrm{C}$ sedangkan parameter $\mathrm{pH}$ berkisar antara $6,9-7,3$. Kisaran nilai suhu dan $\mathrm{pH}$ pada penelitian ini dinilai masih sesuai dengan kisaran nilai kualitas air yang baik untuk pertumbuhan dan kelangsungan hidup ikan nila. Sesuai hasil penelitian Mulyani et.al., (2014) bahwa parameter kualitas air yang optimum untuk pertumbuhan dan kelangsungan hidup ikan nila adalah pada suhu berkisar $27-29^{\circ} \mathrm{C}$ dan pH 6,8-7,3.

\section{Pembahasan}

Nilai tingkat kelangsungan hidup (SR)selama masa pemeliharaan 45 hari berkisar $100 \%$ pada semua perlakuan uji. Hal ini diduga, selama masa pemeliharaan kualitas air didalam kolam sangat mendukung aktivitas metabolisme ikan nila dan idealnya padat tebar didalam media pemeliharaan juga sangat menentukan terhadap kelangsungan hidup. Sesuai dengan hasil penelitian Yurisman et.al., (2010) menyatakan bahwa,pemeliharaan ikan tapah (Wallago sp.) dalam kolam yang diberikan happa dengan padat tebar 6 ekor/happa ditempatkan di kolam dan setelah pemeliharaan selama tiga bulan nilai kelangsungan hidupnya $100 \%$.

Kelangsungan hidup suatuorganisme dipengaruhi oleh dua faktor, yaitu faktor biotik yang terdiri dari kompetitor,kepadatan populasi, umur dan kemampuan organisme dengan lingkungan,sedangkan faktor abiotik terdiri dari suhu, oksigen terlarut, $\mathrm{pH}$ dan kandungan amoniak.Hasil penelitian Sunarto dan Sabariah (2009) juga menunjukkan bahwa perbedaan dosis pemberian pakan tidak berpengaruh terhadap tingkat kelangsungan hidup ikan semah. Hal ini dapat disimpulkan bahwa tingkat kelangsungan hidup tidak dipengaruhi oleh frekuensi pemberian pakan melainkan dipengaruhi oleh kesehatan ikan dan lingkungan.

Pertumbuhan merupakan proses bertambahan panjang dan berat suatu organisme yang dapat dilihat dari perubahan ukuran panjang dan berat dalam satuan waktu. Pertumbuhan ikan dipengaruhi oleh kualitas dan kuantitas pakan, umur dan kualitas air (Mulqan, et.al.,2017). Dari data hasil analisis, rata-rata laju pertumbuhan spesifik 
(SGR) ikan nila gift menunjukan perbedaan pada setiap perlakuan $(\mathrm{P}>0,05)$. Hasil penelitian selama 45 hari diketahui bahwa penambahan sumber protein nabati menggunakan limbah ampas tahu dalam pakan menghasilkan SGR antara 0,56 $2,87 \%$. Nilai SGR tertinggi terdapat pada P1 yaitu $2,87 \%$ dan terendah terdapat pada perlakuan P0 (kontrol) yaitu $0,56 \%$.

Menurut Hidayat et. al. (2013), pertumbuhan dipengaruhi oleh beberapa faktor yaitu faktor dari dalam dan faktor dari luar, adapun faktor dari dalam meliputi sifat keturunan, ketahanan terhadap penyakit dan kemampuan dalam memanfaatkan makanan, sedangkan faktor dari luar meliputi sifat fisika, kimia dan biologi perairan. Menurut Effendie (1997) pertumbuhan merupakan perubahan ukuran ikan baik dalam berat, panjang maupun volume selama periode waktu tertentu yang disebabkan oleh perubahan jaringan akibat pembelahan sel otot dan tulang yang merupakan bagian terbesar dari tubuh ikan sehingga menyebabkan penambahan berat atau panjang ikan.

Dilihat dari parameter SGR, penambahan persentase ampas tahu semakin meningkat maka laju pertumbuhan bobot akan semakin menurun. Hal ini diduga disebabkan, setiap terjadinya peningkatan persentase penambahan ampas tahu maka akan tinggi pula serat kasar yang terkandung didalam pakan tersebut. Menurut Ranjhan(1993) Makanan yang berserat akan menyebabkan bertambahnya energi yang dibutuhkan dalam proses pencernaan. Sesuai penelitian Fauzi, et.al., (2012) Diperkirakan pada ikan yang diberi pelet dengan konsentrasi 10\%, 20\%, $30 \%$ dan $40 \%$, energi yang seharusnya dapat digunakan untuk menambah jaringan tubuh, dikeluarkan untuk proses mencerna pakan yang berserat. Lovell (1989) melaporkan bahwa serat tidak memiliki nilai nutrisi dan kandungan serat yang tinggi pada pakan ikan dapat menurunkan laju tumbuh. Serat yang terkandung dalam pakan bercampur bagas secara langsung akan meningkatkan kadar selulosa dalam pakan. Menurut Mudjiman
(2000), batasan serat yang terkandung dalam pakan ikan adalah $8 \%$.

Selama penelitian, pakan yang diberikan tidak hanya dipengaruhi oleh kandungan serat kasar didalam pakan melainkan juga dipengaruhi oleh kandungan protein dalam pakan tersebut. Mudjiman (2004) menyatakan bahwa kecernaan protein pada ikan umumnya sangat tinggi hingga dapat mencapai lebih dari $90 \%$. Menurut Marzuqi et al., (2006), nilai kecernaan protein yang tinggi itu sangat penting artinya karena protein tersebut merupakan sumber energi utama. Selain digunakan sebagai sumber energi, protein juga digunakan untuk pembentukan sel-sel baru dalam proses pertumbuhan.

Kecernaan protein tergantung pada kandungan protein di dalam pakan. pakan yang kandungan proteinnya rendah, umumnya mempunyai kecernaan yang rendah pula dan sebaliknya. Tinggi rendahnya kecernaan protein tergantung pada kandungan protein bahan pakan dan banyaknya protein yang masuk dalam saluran pencernaan (Tillman et al., 1991).Menurut Angriani, et.al.,(2012) Kenaikan bobot tubuh ikan akan sangat berkaitan dengan jumlah pakan yang mampu dikonsumsi oleh ikan itu sendiri. Pakan akan digunakan untuk kelangsungan hidup dan sisanya digunakan untuk pertumbuhan. Semakin besar bobot ikan maka akan semakin besar pula pakan yang diberikan. Namun saat ikan sudah merasa tercukupi kebutuhan pakannya maka akan ada pakan yang tersisa dari pakan yang diberikan. Pakan yang dikonsumsi oleh ikan merupakan selisih dari jumlah pakan yang diberikan dengan jumlah pakan yang tersisa.

Parameter penunjang dari penelitian ini adalah parameter kualitas air yaitu suhu dan pH. Air sebagai media hidup ikan yang dipelihara harus memenuhi persyaratan. Kualitas air perlu dilakukan pengontrolan agar kualitas air tetap berada dalam kondisi yang optimal, sehingga menciptakan lingkungan yang sesuai dengan habitat ikan nila.Suhu adalah faktor lingkungan yang berpengaruh 
terhadap kecepatan metabolisme tubuh ikan. Selama penelitian ini berlangsung suhu tercatat antara $24-27^{\circ} \mathrm{C}$. Hal ini sesuai dengan Khairuman dan Amri (2003) yang menyatakan suhu air optimal untuk ikan nila merah yaitu $25-30^{\circ} \mathrm{C}$.

Suhu dapat mempengaruhi aktifitas kehidupan organisme seperti nafsu makan ikan (Mulyani, et.al, 2014). Jika suhu meningkat maka akan meningkatkan pengambilan makanan oleh ikan dan turunnya suhu menyebabkan proses pencernaan dan metabolisme akan berjalan lambat (Effendi, 2003).Nilai pH suatu perairan dapat mempengaruhi pertumbuhan bagi biota didalamnya, bahkan dapat menyebabkan kematian. Effendi (2003) menyatakan bahwa sebagian besar biota akuatik menyukai $\mathrm{pH}$ sekitar 7-8,5 dan pada nilai $\mathrm{pH}$ kurang dari 4 maka sebagian besar biota akuatik mati karena tidak dapat bertoleransi terhadap $\mathrm{pH}$ rendah. Selama penelitian berlangsung $\mathrm{pH}$ tercatat antara $6,9-7,3$. Hal ini sesuai dengan pernyataan Khairuman dan Amri (2003) bahwa kisaran $\mathrm{pH}$ yang diperlukan oleh ikan nila yaitu 6-9. Nilai $\mathrm{pH}$ dalam penelitian ini juga sependapat dengan Putri et.al., (2012) derajat keasaman yang masih ditolerir oleh ikan nila yaitu berkisar $6-7,9$.

KESIMPULAN

Penambahan sumber protein nabati menggunakan limbah ampas tahu, memberikan pengaruh nyata $(\mathrm{P}>0,05)$ terhadap pertumbuhan benih ikan nila gift (Oreochromis niloticus). Penggunaan limbah ampas tahu sebanyak 10\% memberikan performa pertumbuhan yang baik pada ikan nila.

\section{DAFTAR PUSTAKA}

Angriani, R. Iskandar dan Ankiq, T. 2012. Efektivitas Penambahan Bacillus sp. Hasil Isolasi Dari Saluran Pencernaan Ikan Patin Pada Pakan Komersial Terhadap Kelangsungan Hidup Dan Pertumbuhan Benih Ikan Nila Merah
(Oreochromis niloticus).Jurnal Perikanan dan Kelautan. ISSN : 20883137Vol. 3, No. 3. Hal : 75-83

Effendi, H. 2003. Telaah Kualitas Air.Kanisius. Yogyakarta.

Effendie, M.I. 1997. Biologi Perikanan. Yayasan Pustaka Nusatama. Yogyakarta.

Fauzi, Y. A. Ekowati. C.N. Susanto, G.N. dan Mucharomah, P. 2012. Tingkat Pertumbuhan Spesifik Dan SintasanIkan Nila (Oreochromis niloticus Linn.) Melalui Pemberian Pakan Pelet Bercampur BagasYang Difermentasi Dengan Isolat Jamur. Prosiding SNSMAIP III. ISBN No. 978-602-98559-1-3

Hidayat D, Ade. D. S, Yulisma. 2013. Kelangsungan hidup, pertumbuhan dan efesiensi pakan ikan gabus (Channa striata) yang diberi pakan berbahan bakutepung keong mas (Pomacea $s p$ ). Jurnal akuakultur rawa indonesia. 1 (2) :161-172.

Khairul dan Amri. 2003. Budidaya Ikan Nila Secara Intensif. AgroMedia Pustaka.Jakarta.

Lovell, T. 1989. Nutrition and Feed of Fish. Book van Nostrand reinhold, New York, $261 \mathrm{pp}$.

Marzuqi, M., N.A. Giri., K. Suwirya. 2007. Kebutuhan protein optimal dan kecernaan nutrien pakan untuk benih ikan kerapu sunu (Plectropomus leopardus). Jurnal Aquacultura Indonesiana, 8(2): 113-119.

Mudjiman, A. 2000. Makanan Ikan. Penebar Swadaya, Jakarta.

Mudjiman, A. 2004. Makanan ikan. Penebar Swadaya, Jakarta.

Mulia, D.S., M. Mudah, H. Maryanto, \& C. Purbomartono. 2014. Fermentasi AmpasTahu dengan Aspergillus niger untuk Meningkatkan Kualitas Bahan Baku PakanIkan. Prosiding Seminar Nasional Hasil-Hasil Penelitian dan Pengabdian.LPPM Universitas Muhammadiyah Purwokerto.324-332. 
Mulqan, M. Rahimi, S.A.E. Irma, D. 2017. Pertumbuhan dan Kelangsungan Hidup Benih Ikan Nila Gesit/Oreochromis niloticus) Pada Sistem Akuaponik Dengan Jenis Tanaman Yang Berbeda. Jurnal Ilmiah Mahasiswa Kelautan dan Perikanan Unsyiah. ISSN. 2527-6395. Vol 2, No. 1: 183-193

Mulyani, Y.S. Yulisman. Mitra, F. 2014. Pertumbuhan Dan Efisiensi Pakan Ikan Nila (Oreochromis niloticus) Yang Dipuasakan Secara Periodik. Jurnal Akuakultur Rawa Indonesia, ISSN : 2303-2960. Vol. 2, No. 1 :01-12

Mursining., 2006. Teknik Pembesaran Ikan Kelemak (Leptobarbus hoeveni Blkr) DenganPemberian Kombinasi Pakan Berbeda. Skripsi Fakultas Perikanan dan Ilmu Kelautan. Universitas Riau. Pekanbaru. 40 hal.

Putri, F.S. Hasan, Z. dan Kiki, H. 2012. Pengaruh pemberian bakteri prbiotik pada pellet yang mengandung kaliandra (Calliandracalothyrsusu) terhadap pertumbuhan benih ikan nila (Oreochromis niloticus).Jurnal Perikanan dan Kelautan. ISSN : 20883137. Vo, 3, No. 4. Hal : 283-291

Ranjhan, S.K., 1993. "Animal Nutrition andFeeding Practices“. Vikas PublishingHouse PVT LTD. India.

Rasidi. 1998.Formulasi Pakan Lokal Alternatif Untuk Unggas. Jakarta:Penebar Swadaya.

Sunarto dan Sabariah. 2009. Pemberian Pakan Buatan dengan Dosis Berbeda terhadap Pertumbuhan dan Konsumsi Pakan Benih Ikan Semah (Tor Douronensis) dalam Upaya Domestikasi. Jurnal Akuakultur Indonesia, 8 (1):67-76.

Winarno FG. 2008. Kimia Pangan dan Gizi. Bogor: MBrio Press.

Yurisman, Sukendi, Putra, R.M. 2010. Domestikasi dan Pematangan Gonad Ikan Tapah (Wallago leerii) dari Perairan sungai kampar Riau. Pekanbaru. Jurnal Terubuk, 38(1) : 107117 